\title{
Quality Evaluation of Soycorn Yoghurt Fermented with Starter Culture and Corn Steep Water
}

\author{
Adeoye Bolade K. ${ }^{1}$, Ani Ime F. ${ }^{1}$, Adeyeye Joshua A. ${ }^{1}$, \\ Ngozi Elizabeth $0 .{ }^{1}$, Adebiyi Raheemat A. ${ }^{1}$
}

\author{
${ }^{1}$ Department of Nutrition and Dietetics, Babcock University, P.M.B. 21244 Ikeja Lagos, Nigeria
}

\begin{abstract}
This study aimed at producing yoghurt from corn and soybean milk using starter culture and corn steep water for fermentation and evaluating its qualities. Yoghurt was produced from three blends of corn milk and soymilk (70:30, 50:50, 30:70) and starter culture (Streptococcus thermophilus and Lactobacillus bulgaricus) and corn steep water were used for fermentation for $16 \mathrm{~h}$ at $36{ }^{\circ} \mathrm{C}$ respectively. After fermentation the yoghurt samples were refrigerated for $3 \mathrm{~h}$ to terminate the process of fermentation and the yoghurt samples were homogenized, sweetened and flavoured. The physico-chemical properties, physical properties, chemical composition and microbiological quality of the yoghurt samples were determined. Organoleptic properties of the yoghurt samples was evaluated using 10- membered panel and the yoghurt samples were compared with Hollandia yoghurt. All results were subjected to analysis of variance (ANOVA) at $\mathrm{P}<0.05$ and means were separated using Duncan multiple range tests. The $\mathrm{pH}(6.1-6.3)$ of the samples was not significantly different before fermentation but became significantly different after fermentation (4.0-4.4) at $\mathrm{P}<0.05$. The titratable acidity was $0.17 \%$ before fermentation but was $0.66-1.07 \%$ which was significantly different after fermentation. The specific gravity before fermentation ranged from 1.01- 1.02 and 1.01 and 1.03 after fermentation with no significant difference. There was significant difference in the syneresis $(16.3-27.4 \%)$ with samples fermented with starter culture having higher rate of syneresis. Chemical composition of the samples differ significantly though there was no marked difference between samples fermented with starter culture and corn steep water. The lactic acid bacteria count ranged between $1.0 \times 10^{4}$ $-5.0 \times 10^{4} \mathrm{Cfu} / \mathrm{ml}$ and the results of sensory evaluation showed that there was no significant difference in all the yoghurt samples except the control. Thus, there was no marked difference in the qualities of soycorn yoghurt fermented with starter culture and soycorn yoghurt fermented with corn steep water.
\end{abstract}

Keywords: Fermentation, Soycorn, Starter Culture, Steep Water, Yoghurt

\begin{abstract}
Introduction
Yoghurt is a Turkish name for a fermented milk product which was originated by early normadic herdsman, which were in Asia, Southern and Eastern Europe. Yoghurt is made by adding a culture of acid forming bacteria to milk that is usually homogenized, pasteurized and fermented (Salje et al., 2006; Popoola et al., 2007). It is a fermented product which was initially invented to prolong the shelf life of fresh milk (Tamime and Robinson, 1989). Fermentation of milk sugar (lactose) produces lactic acid, which acts on milk protein to give yoghurt its texture and its characteristics tang (Moore, 2004). Yoghurt can be presented in different varieties; as set or stirred (drinking) yoghurt, plain and partly skimmed, sweetened and flavoured forms (Imele and Atemnkeng, 2001) products.
\end{abstract}

Cow milk is used in the production of most commercial yoghurt because of its authentic taste and aroma, and also its nutritional value which is very beneficial for health. In the production yoghurt, probiotic microorganisms are used (Ataie-jafari et al., 2009) and consumption of probiotics has been reported to result in several therapeutic effects (Lourens-Hattingh and Viljoen, 2001) such as lowering the cholesterol level of serum cholesterol (Agerbeak et al., 1995: Anderson and Gilliand 1999: Agerholm-Larsen 2000), It is also said that eating yoghurt containing 1-achidophilus helps prevent Vulvovirgina candidiasis (Ringdal, 2000). Also, consumption of probiotics in such food product like yoghurt is essential for keeping the gut healthy by maintaining natural microbes which help to prevent certain diseases and also has implication on the health generally.

This article is published under the terms of the Creative Commons Attribution License 4.0 Author(s) retain the copyright of this article. Publication rights with Alkhaer Publications. Published at: http://www.ijsciences.com/pub/issue/2019-03/

DOI: 10.18483/ijSci.1974; Online ISSN: 2305-3925; Print ISSN: 2410-4477 
Milk and milk products are generally expensive which made yoghurt to be out of reach of many despite its benefit which is rare. Also, yoghurt from cow milk contains saturated fats and saturated fat has been linked with a lot of degenerative diseases like cardio-vascular disease.

Production of yoghurt with food commodities that are readily available and inexpensive will promote its consumption, improve health as a result of limiting consumption of saturated fat and people suffering from lactose intolerance will also benefit. In this regard there has been a number of researches on finding an alternative source of milk for producing yoghurt with the aim of substituting plant based milk for the cow milk.

Production of yoghurt from corn and soybean milk could be a new innovation in the making of yoghurt. This effort is paramount in that present consumption of yoghurt is limited to certain class of people as it is not affordable by low income group but as a result of its health benefit there is a need to find an alternative method of production so as to reduce its price and make it easily accessible to everyone. Based on these reasons, developing a new corn and soybean based product in form of healthy yoghurt is an avenue to encourage consumption of probiotics in a product like yoghurt (Supavititpatana et al. 2008) in Africa.

\section{Materials and methods \\ Materials}

Yellow variety of corn (Zea mays) that was freshly harvested was purchased from a farmer in IlishanRemo while soybean (Glycine max) and sugar were purchased from Ilishan - Remo market in Ogun State, Nigeria. The strawberry flavour and pink colouring were bought at Sabo market in Shagamu whereas the starter culture (CHR HANSEN YC-38 thermophilic yoghurt culture) was purchased from Just rite supermarket in Ota, Ogun State Nigeria. The corn steep water from freshly prepared corn mash was obtained from Babcock University Cafeteria.

\section{Preparation of corn milk}

Fresh and matured corn with high moisture content and which contains high concentration of sugar was used. The husk was removed and the grain separated from the cob. Extraneous materials and silk from the corn were removed (Floyed and Brandon, 1995) before weighing. The corn was washed with portable water, after which it was blended and filtered through a muslin material to extract milk of fine consistency. The steps involved in the processing are as in fig. 1.

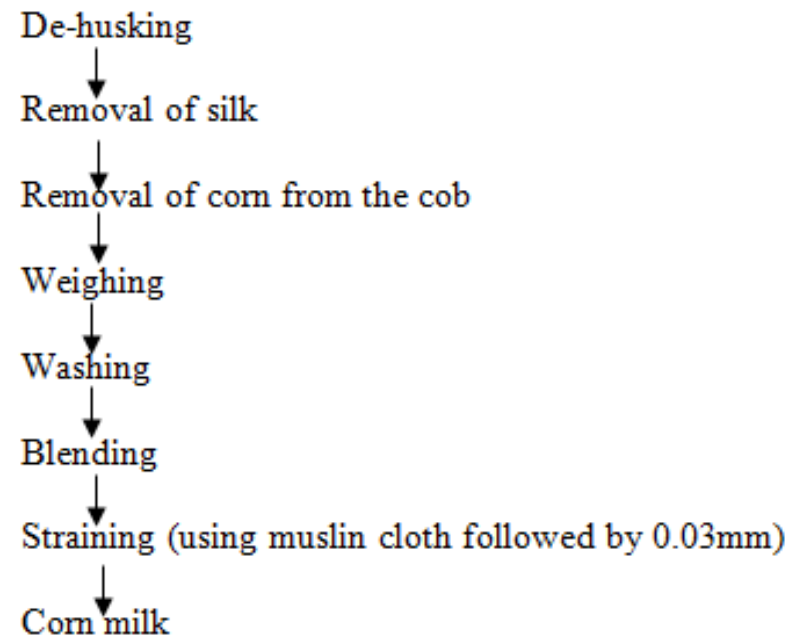

Fig 1: Preparation of corn milk

\section{Preparation of soymilk}

The flowchart for preparation of soymilk is presented in fig. 2. The soybeans were picked to remove stones and any other contaminants. $500 \mathrm{~g}$ of healthy and unbroken soybean seed

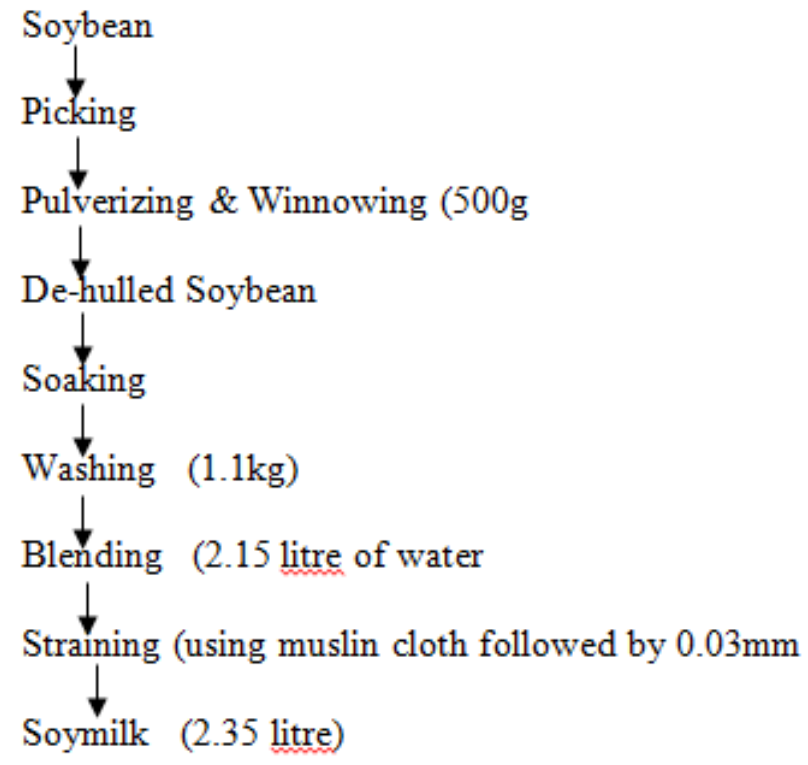

Fig 2: Preparation of Soymilk

were pulverized and winnowed to remove the seed coat. It was then soaked in water for $4 \mathrm{~h}$ and washed with portable water. The soybean was blended and the soymilk slurry was mixed with water while breaking lumps to allow for fast sieving. Water was added to the slurry, and the soymilk was obtained by passing the slurry through a muslin material to separate the milk from the mash (Osho, 1991; Iwe 1991). 


\section{Preparation of soycorn yoghurt}

Six samples of different blends of corn and soymilk yoghurt were formulated. Three samples of mixture of corn milk and soymilk were fermented using starter culture containing Streptococcus thermophillus and Lactobacillus bulgaricus. The remaining three samples of mixture of corn milk and soymilk were fermented using corn steep water. The ratio of corn milk to soymilk used was 70:30, 50:50 and 30:70. The method of (Belewu et al., 2005) with some modifications was used for the production of the yoghurt. Added to the milk mixtures were $5 \mathrm{~g}$ of sugar to aid the fermentation and $1 \mathrm{~g}$ of gelatin to improve the yoghurt consistency. The different mixtures of the two milk samples were heated separately to a temperature of $60{ }^{\circ} \mathrm{C}$ for $30 \mathrm{~min}$, then cooled rapidly to a temperature of $40{ }^{\circ} \mathrm{C}$. Each of the treatment was inoculated with starter culture $(0.4 \mathrm{~g}$ dissolved in $2 \mathrm{ml}$ of warm water to $500 \mathrm{ml}$ of milk) and corn steep water ( $7 \mathrm{ml}$ to $500 \mathrm{ml}$ of milk) as stated above. Fermentation was at $36{ }^{\circ} \mathrm{C}$ in an enclosed area. After complete fermentation duration of $16 \mathrm{~h}$, the samples were put in the refrigerator for 3 $\mathrm{h}$ to stop the fermentation. To the yoghurt samples was added $20 \mathrm{~g}$ of sugar, $1 \mathrm{ml}$ of strawberry flavour and pink colouring, the samples were bottled in plastic bottles with screw cap and the yoghurt samples stored in the refrigerator at $4 \pm 2{ }^{\circ} \mathrm{C}$ for analysis. Figure 3 shows the processing step

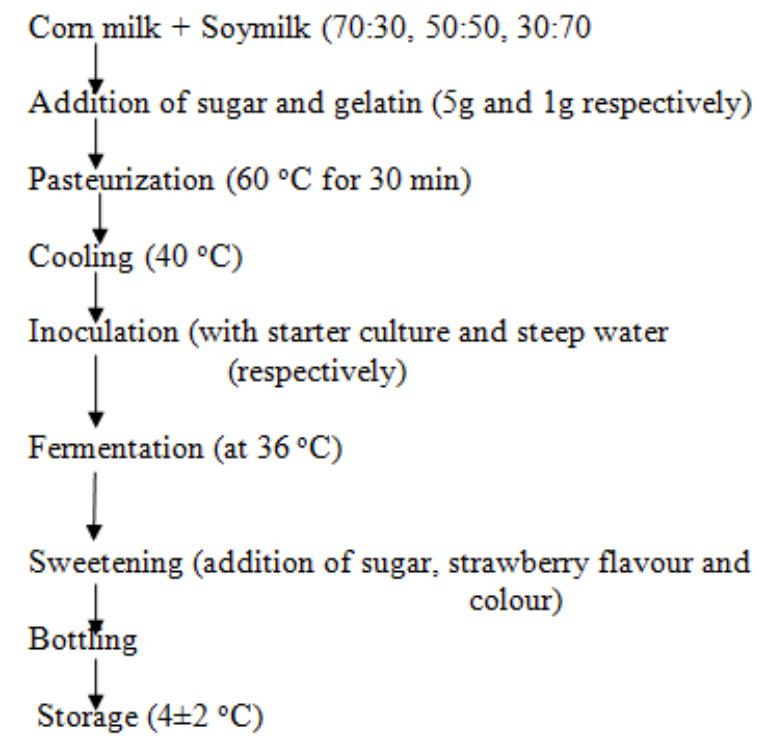

Fig 3: Preparation of soycorn yoghurt (Belewu et al, 2005).

Analytical methods

Physico - chemical properties

pH and Titratable acidity
$\mathrm{pH}$ was measured using $\mathrm{pH}$ meter and total titratable acidity was measured according to AOAC (2015). 20 $\mathrm{ml}$ of the yogurt sample was made up to $100 \mathrm{ml}$ with distilled water and $10 \mathrm{ml}$ was titrated with $0.1 \mathrm{~N}$ $\mathrm{NaOH}$ using $1 \%$ phenolphthalein as an indicator.

Percentage acid $=\frac{\text { titre } \mathrm{x} \text { acid factor } \mathrm{x} 100 \mathrm{x} \text { dilution factor }}{10 \mathrm{ml} \text { of sample }}$

\section{Physical properties}

Specific gravity

Specific gravity was determined by the method described by AOAC (2015). Specific gravity compares the weight of a liquid with equal volume of water. A clean density bottle was weighed empty, it was then filled to the brim with water and weighed before being filled with the yoghurt sample. The density bottle was wiped dry in case of any spillage from filling and the cork was inserted in each process.

The density of the sample was calculated as follows: Weight of sample-filled bottle - weight of empty bottle Weight of water-filled bottle - weight of empty bottle

\section{Syneresis}

Syneresis was measured according to Supavititpatana et al. (2007) with modification. Sterile empty cup was weighed, filled up with $50 \mathrm{ml}$ of yoghurt sample aseptically, incubated for $7 \mathrm{~h}$ at $42{ }^{\circ} \mathrm{C}$, and then allowed to stand at $4{ }^{\circ} \mathrm{C}$ in a refrigerator for $24 \mathrm{~h}$, the liquid that separated from the solid was weighed. Syneresis was done two weeks after production of the yoghurt was produced

\section{Chemical analysis \\ Moisture content}

The moisture content of the samples was determined according to the method described by AOAC (2015). The sample was weighed into a petri dish and heated in an oven at $100{ }^{\circ} \mathrm{C}$ for two and half hours. The sample was cooled in a dessicator for $30 \mathrm{~min}$ and weighed. This sample was reheated in the oven for another one hour, cooled and reweighed. This was repeated until weight loss between successive weighing become negligible.

$$
\% \text { Moisture }=\frac{\mathrm{M} \text { initial }-\mathrm{M} \text { dried }}{\mathrm{M} \text { initial }} \times 100
$$

\section{Ash content}

Ash content was determined as described by AOAC (2015) method. About $2 \mathrm{~g}$ of the sample was weighed into a crucible of known weight. The content in the crucible was dried in an oven before being placed in a muffle furnace for $12 \mathrm{~h}$ until gray or ash colour was obtained. Using a crucible tong, the crucible was transferred to a desiccator and allowed to cool. The 
crucible and ash was reweighed. The percentage ash content was then calculated.

$\%$ Ash $=\underline{\text { Ash weight (grm) } \times 100}$

\section{Fat content}

$$
\text { Sample weight }
$$

The fat was determined by Werner Schmid method as described by AOAC (2015). About $10 \mathrm{~g}$ of the yoghurt sample was weighed into an extraction thimble and $10 \mathrm{ml}$ of concentrated HCL was added. The thimble was immersed in a water bath until the casein content (protein) was dissolved. The fat was extracted by shaking with $30 \mathrm{ml}$ of dethyl ether into a weighed flask and $10 \mathrm{ml}$ of alcohol was added to aid the separation in the funnel. The fat was dried at 100 ${ }^{\circ} \mathrm{C}$, cooled and weighed.

\section{Protein content}

The protein content was determined by the formol titration method (AOAC, 2015). $10 \mathrm{ml}$ of yoghurt sample was transferred into $250 \mathrm{ml}$ conical flask using $10 \mathrm{ml}$ of pipette, 3 drops of phenolphthalein indicator was added, then 2 drops of natural saturated potassium oxalate was added, the mixture was mixed thoroughly in the flask and was allowed to stand for a few minutes. The mixture was neutralized with $0.1 \mathrm{~m}$ $\mathrm{NaOH}$ to a faint pink coloration.

Then $2 \mathrm{ml}$ of formaldehyde (formalin) was added and mixed thoroughly, it was allowed to stand for a few minutes, then continue the titration with $0.1 \mathrm{~m} \mathrm{NaOH}$ in the burette to a faint pink coloration. A blank titration was carried out using $10 \mathrm{ml}$ of water plus the addition of 3 drops of phenolphthalein, 2 drops of potassium oxalate, $2 \mathrm{ml}$ of formalin and titrated with $0.1 \mathrm{~mol} \mathrm{NaOH}$ to a faint pink coloration.

Calculation;

$\%$ Protein $=1.7(\mathrm{a}-\mathrm{b}) \%$ where,

$\mathrm{a}=$ the titre value of sample.

$b=$ the titre value of blank.

\section{Carbohydrate}

The carbohydrate content of the yoghurt was determined by difference according to AOAC (2015). $\% \mathrm{CHO}=[100-(\mathrm{M} . \mathrm{C}+$ protein + fat + Ash $)]$ Where $\mathrm{MC}=$ moisture content

\section{Determination of Total Lactic Acid Bacteria (LAB)}

Serial dilution of the yoghurt samples was done using sterilized peptone water. Four fold dilutions of the samples were made. Using separate sterile pipette $1 \mathrm{ml}$ of each diluted solution of 10-4 was pipetted into separate, duplicate, appropriately marked petri dishes. $15 \mathrm{ml}$ of de Man Rogosa Sharpe (MRS) agar which was prepared according to the manufacturer instruction (cooled to $50 \pm 1{ }^{\circ} \mathrm{C}$ ) was poured into each plate. The MRS agar was supplemented with nystatin $(50 \mathrm{mg} / \mathrm{ml})$ to prevent the growth of fungi. The mixture was immediately mixed thoroughly and uniformly by alternate rotation and back-and-forth motion of plates on flat level surface. Agar was left to solidify and then incubated for $48 \mathrm{~h}$ at $37^{\circ} \mathrm{C}$. Colonies of lactic acid bacteria which grow on the medium were enumerated (Lestiyani, 2014).

\section{Sensory analysis}

The yoghurt samples were compared with commercially produced yoghurt (Hollandia strawberry flavoured yoghurt) and a ten-membered untrained panel which consist of students of Nutrition and Dietetics was used to evaluate the various sensory parameters (flavour, colour, taste, viscosity and overall acceptability). The scores were based on a hedonic scale ranging from 1 representing dislike extremely to 9 representing like extremely (Iwe, 2002).

\section{Statistical analysis}

Data obtained were subjected to Analysis of variance (ANOVA) and means were

separated using the Duncan multiple range tests (SPPS 20.0).

\section{RESULTS}

\section{Physico-chemical properties}

The results of $\mathrm{pH}$ and titratable acidity of the yoghurt samples are as shown in Table 1. The $\mathrm{pH}$ before fermentation ranged between 6.1 and 6.3 which were not significantly different at $\mathrm{P}<0.05$ while the $\mathrm{pH}$ was significantly different after fermentation and it ranged between 4.0 and 4.4 . The titratable acidity was 0.17 for all the samples before fermentation but after fermentation there was significant difference in the titratable acidity of the samples which ranged between 0.66 and 1.07. 
Table 1: Physicochemical characteristics of the yoghurt samples

\begin{tabular}{|c|c|c|c|c|}
\hline \multirow[t]{2}{*}{ Samples } & \multicolumn{2}{|c|}{$\mathrm{Ph}$} & \multicolumn{2}{|c|}{ Titratable acidity (\%) } \\
\hline & $\begin{array}{l}\text { Before } \\
\text { fermentation }\end{array}$ & $\begin{array}{l}\text { After } \\
\text { fermentation }\end{array}$ & $\begin{array}{l}\text { Before } \\
\text { fermentation }\end{array}$ & $\begin{array}{l}\text { After } \\
\text { fermentation }\end{array}$ \\
\hline $\mathrm{A}$ & $6.2^{\mathrm{a}}$ & $4.0^{\mathrm{b}}$ & $0.17^{\mathrm{a}}$ & $0.98^{\mathrm{ab}}$ \\
\hline B & $6.3^{\mathrm{a}}$ & $4.1^{b}$ & $0.17^{\mathrm{a}}$ & $0.89^{\mathrm{b}}$ \\
\hline $\mathrm{C}$ & $6.1^{\mathrm{a}}$ & $4.0^{\mathrm{b}}$ & $0.17^{\mathrm{a}}$ & $1.07^{\mathrm{a}}$ \\
\hline $\mathrm{D}$ & $6.2^{\mathrm{a}}$ & $4.0^{\mathrm{b}}$ & $0.17^{\mathrm{a}}$ & $1.07^{\mathrm{a}}$ \\
\hline $\mathrm{E}$ & $6.3^{\mathrm{a}}$ & $4.4^{\mathrm{a}}$ & $0.17^{\mathrm{a}}$ & $0.66^{\mathrm{b}}$ \\
\hline $\mathrm{F}$ & $6.1^{\mathrm{a}}$ & $4.2 \mathrm{a}^{\mathrm{b}}$ & $0.17^{\mathrm{a}}$ & $0.98^{\mathrm{b}}$ \\
\hline
\end{tabular}

Means with the same superscript along the column are not significantly different $(\mathrm{p}<0.05)$

A : yoghurt sample with 50\%soybean and 50\%corn fermented with starter culture

B: yoghurt sample with $30 \%$ corn and $70 \%$ soybean fermented with starter culture

C: yoghurt sample with $70 \%$ corn and $30 \%$ soybean fermented with starter culture

D yoghurt sample with 50\%corn and 50\% soybean fermented with corn steep water

E: yoghurt sample with $70 \%$ soybean and $30 \%$ corn fermented with corn steep water

F: yoghurt sample with $70 \%$ corn and $30 \%$ soybean fermented with corn steep water

\section{Physical properties}

Table 2 showed the specific gravity and syneresis of the yoghurt samples. The specific gravity was between 1.01 and 1.02 before fermentation and after fermentation there was a slight change and it ranged between 1.01-1.03. The syneresis of the soycorn yoghurt was between 12.6 and 27.4 which was significantly different at $\quad \mathrm{P}<0.05$.

Table 2: Physical properties of the yoghurt samples

\begin{tabular}{llll}
\hline Samples & $\begin{array}{l}\text { Specific gravity } \\
\text { Before fermentation }\end{array}$ & $\begin{array}{l}\text { Specific gravity } \\
\text { After fermentation }\end{array}$ & Syneresis (\%) \\
\hline A & $1.01^{\mathrm{a}}$ & $1.02^{\mathrm{a}}$ & $16.3^{\mathrm{d}}$ \\
$\mathrm{B}$ & $1.01^{\mathrm{a}}$ & $1.01^{\mathrm{a}}$ & $27.4^{\mathrm{f}}$ \\
$\mathrm{C}$ & $1.02^{\mathrm{a}}$ & $1.03^{\mathrm{a}}$ & $24.9^{\mathrm{e}}$ \\
$\mathrm{D}$ & $1.01^{\mathrm{a}}$ & $1.02^{\mathrm{a}}$ & $12.6^{\mathrm{a}}$ \\
E & $1.01^{\mathrm{a}}$ & $1.02^{\mathrm{a}}$ & $15.0^{\mathrm{b}}$ \\
F & $1.02^{\mathrm{a}}$ & $1.03^{\mathrm{a}}$ & $15.9^{\mathrm{c}}$
\end{tabular}

Means with the same superscript along the column are not significantly different $(\mathrm{p}<0.05)$

A: yoghurt sample with 50\%soybean and 50\%corn fermented with starter culture

B: yoghurt sample with $30 \%$ corn and $70 \%$ soybean fermented with starter culture 
C: yoghurt sample with $70 \%$ corn and $30 \%$ soybean fermented with starter culture

D yoghurt sample with 50\%corn and 50\% soybean fermented with corn steep water

E: yoghurt sample with $70 \%$ soybean and $30 \%$ corn fermented with corn steep water

F:yoghurt sample with $70 \%$ corn and $30 \%$ soybean fermented with corn steep water

\section{Proximate composition}

There was significant difference $(\mathrm{P}<0.05)$ in the composition of the yoghurt samples except fat (Table
3 ). The moisture content was from $88.6 \%$ to $91.0 \%$, ash $(0.1-0.6 \%)$, protein $(2.61-3.49 \%)$, fat $(0.78$ $1.15 \%)$ and carbohydrate $(4.0-9.6 \%)$.

Table 3: Proximate composition of the yoghurt samples

\begin{tabular}{cccccc} 
Sample & $\begin{array}{c}\text { Moisture Content } \\
(\%)\end{array}$ & $\begin{array}{c}\text { Ash Content } \\
(\%)\end{array}$ & $\begin{array}{c}\text { Protein } \\
(\%)\end{array}$ & $\begin{array}{c}\text { Fat } \\
(\%)\end{array}$ & $\begin{array}{c}\text { Carbohydrate } \\
(\%)\end{array}$ \\
\hline A & $88.6^{\mathrm{bc}}$ & $0.6^{\mathrm{b}}$ & $3.03^{\mathrm{c}}$ & $0.99^{\mathrm{a}}$ & $6.78^{\mathrm{b}}$ \\
B & $91.0^{\mathrm{ab}}$ & $0.5^{\mathrm{c}}$ & $2.61^{\mathrm{f}}$ & $1.08^{\mathrm{a}}$ & $4.81^{\mathrm{d}}$ \\
C & $92.0^{\mathrm{a}}$ & $0.3^{\mathrm{e}}$ & $2.69^{\mathrm{d}}$ & $0.78^{\mathrm{a}}$ & $4.23^{\mathrm{e}}$ \\
D & $91.6^{\mathrm{ab}}$ & $0.1^{\mathrm{f}}$ & $3.14^{\mathrm{b}}$ & $1.15^{\mathrm{a}}$ & $4.00^{\mathrm{f}}$ \\
E & $89.0^{\mathrm{abc}}$ & $0.8^{\mathrm{a}}$ & $3.49^{\mathrm{a}}$ & $0.87^{\mathrm{a}}$ & $5.80^{\mathrm{c}}$ \\
F & $86.3^{\mathrm{c}}$ & $0.4^{\mathrm{d}}$ & $2.61^{\mathrm{e}}$ & $1.09^{\mathrm{a}}$ & $9.60^{\mathrm{a}}$
\end{tabular}

Means with the same superscript along the column are not significantly different $(\mathrm{p}<0.05)$

A: yoghurt sample with 50\%soybean and 50\%corn fermented with starter culture

B: yoghurt sample with $30 \%$ corn and $70 \%$ soybean fermented with starter culture

C: yoghurt sample with $70 \%$ corn and $30 \%$ soybean fermented with starter culture

D yoghurt sample with 50\%corn and 50\%soybean fermented with corn steep water

E: yoghurt sample with $70 \%$ soybean and 30\%corn fermented with corn steep water

F: yoghurt sample with $70 \%$ corn and $30 \%$ soybean fermented with corn steep water

\section{Lactic acid bacteria}

The lactic acid bacteria of the yoghurt samples ranged between $1.0 \times 10^{-4}$ and $5.0 \times 10^{-4} \mathrm{Cfu} / \mathrm{ml}$ (Fig. I). Yoghurt sample containing $70 \%$ corn and $30 \%$ soybean fermented with starter culture and steep water respectively had the highest content of lactic acid bacteria while yoghurt sample containing 50\% corn and 50\% soybean fermented with corn steep water contain the least amount of lactic acid bacteria.

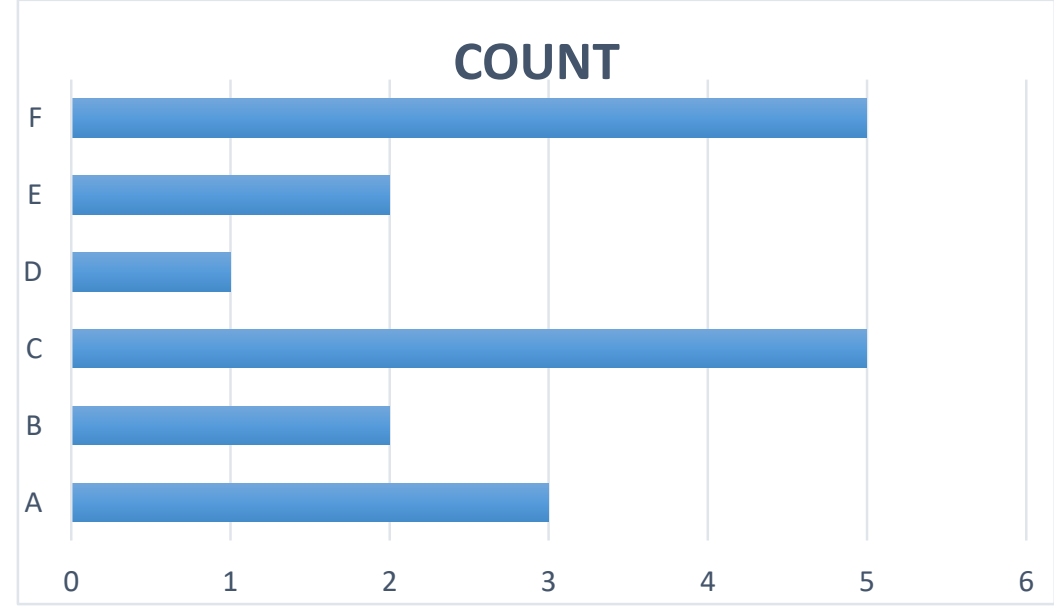

Fig 1: Lactic acid bacteria count $\left(10^{4} \mathrm{cfu}\right)$ of the yoghurt samples 
A: yoghurt sample with 50\%soybean and 50\%corn fermented with starter culture

B: yoghurt sample with $30 \%$ corn and $70 \%$ soybean fermented with starter culture

C: yoghurt sample with $70 \%$ corn and $30 \%$ soybean fermented with starter culture

D yoghurt sample with 50\%corn and 50\%soybean fermented with corn steep water

E: yoghurt sample with $70 \%$ soybean and $30 \%$ corn fermented with corn steep water

F: yoghurt sample with $70 \%$ corn and $30 \%$ soybean fermented with corn steep water

\section{Sensory qualities}

The soycorn yoghurt samples were not significantly different in colour, aroma, viscosity, taste and acceptability but were all significantly different $(\mathrm{P}<0.05)$ from the control in all the parameters except colour.

Table 4: Sensory qualities of yoghurt samples

\begin{tabular}{llllll}
\hline Samples & Colour & Aroma & Viscosity & Taste & Acceptability \\
\hline A & $6.50^{\mathrm{a}}$ & $5.30^{\mathrm{b}}$ & $5.00^{\mathrm{b}}$ & $5.50^{\mathrm{b}}$ & $5.50^{\mathrm{b}}$ \\
B & $6.50^{\mathrm{a}}$ & $5.00^{\mathrm{b}}$ & $5.00^{\mathrm{b}}$ & $4.90^{\mathrm{b}}$ & $5.50^{\mathrm{b}}$ \\
C & $6.80^{\mathrm{a}}$ & $5.60^{\mathrm{b}}$ & $5.70^{\mathrm{b}}$ & $5.40^{\mathrm{b}}$ & $5.70^{\mathrm{b}}$ \\
$\mathrm{D}$ & $6.70^{\mathrm{a}}$ & $6.20^{\mathrm{b}}$ & $5.50^{\mathrm{b}}$ & $5.30^{\mathrm{b}}$ & $6.10^{\mathrm{b}}$ \\
E & $7.10^{\mathrm{a}}$ & $5.80^{\mathrm{b}}$ & $5.30^{\mathrm{b}}$ & $4.60^{\mathrm{b}}$ & $5.40^{\mathrm{b}}$ \\
F & $8.10^{\mathrm{a}}$ & $5.30^{\mathrm{b}}$ & $5.70^{\mathrm{b}}$ & $4.10^{\mathrm{b}}$ & $5.40^{\mathrm{b}}$ \\
Control & $8.00^{\mathrm{a}}$ & $8.50^{\mathrm{a}}$ & $7.90^{\mathrm{a}}$ & $8.40^{\mathrm{a}}$ & $8.60^{\mathrm{a}}$ \\
\hline
\end{tabular}

Means with the same superscript along the column are not significantly different $(\mathrm{p}<0.05)$

A: yoghurt sample with 50\%soybean and 50\%corn fermented with starter culture

B: yoghurt sample with $30 \%$ corn and $70 \%$ soybean fermented with starter culture

C: yoghurt sample with $70 \%$ corn and $30 \%$ soybean fermented with starter culture

D yoghurt sample with 50\%corn and 50\%soybean fermented with corn steep water

E: yoghurt sample with $70 \%$ soybean and 30\%corn fermented with corn steep water

F: yoghurt sample with $70 \%$ corn and $30 \%$ soybean fermented with corn steep water

\section{Discussion}

The $\mathrm{pH}$ of the samples was between 6.1 and 6.3 and the titratable acidity was 0.17 for all the samples before fermentation. However, during fermentation there was a breakdown of sugar by the lactic acid bacteria to produce lactic acid which lowers the $\mathrm{pH}$ and increase the level of acidity. Thus, after fermentation the $\mathrm{pH}$ of the samples were between 4.0 and 4.4 which is comparable to what was reported by Makanjuola (2012) for soycorn. Also, the titratable acidity of the samples ranged between $0.66-1.07 \%$ after fermentation and this was found to be higher than 0.6 recommended by Ministry of Public Health for yoghurt (Supavititpatana et al., 2010).

Specific gravity of the samples determined before and after fermentation was not significantly different though there was slight increase in the specific gravity after fermentation. However, there was a wide difference in the syneresis of the soycorn yoghurt samples and the observed syneresis in the samples was lower than what was reported by Supavititpatana et al. (2010) for corn yoghurt (29.82\%) and cow milk yoghurt $(76.66 \%)$.

The results of the proximate composition showed that the moisture content of the samples ranged between
86.3-92.0\%, protein, 2.61-3.49\%, fat was between $0.78-1.15 \%$, ash was $0.1-0.8 \%$ and carbohydrate was between $4.0-9.6 \%$. However, there was no marked difference between yoghurt samples fermented by culture and steep water. The nutritional content of the yoghurt samples was comparable to the reports of Supavititpatana et al. (2010) and Makanjuola (2012) for corn yoghurt and soycorn yoghurt respectively. Also, the protein is comparable to $3.89 \%$ for protein and the fat content is lower than $3.46 \%$ reported for cow milk yoghurt (Supavititpatana et al., 2010). The Lactic acid bacteria count was between $1.0-5.0 \times 10^{4}$ and these values were found to be lower than $\geq 10^{6}$ recommended for probiotics (Tamime and Robinson,1999) but higher than $0.69-6.13 \times 10^{1}$ reported by Farinde et al. (2008).

The results of sensory evaluation (Table 4) showed that the control was significantly different from the yoghurt samples in all the parameters except colour. However, the yoghurt samples were not significantly different from one another at $\mathrm{P}<0.05$ meaning that there was no significant difference between yoghurt samples fermented with steep water and starter culture. 


\section{Conclusion}

Fermentation with starter culture produced yoghurt with more titratable acidity but with high rate of syneresis. There was no marked difference in the chemical composition, microbiological quality and organoleptic properties of yoghurt produced using starter culture and steep water for fermentation.

\section{References}

1. Agerbeak M, Gerdes LU and Richelsen B, 1995. Hypocholesterol effect of a new fermented milk product in healthy middle-aged men. Eur J Clin Nutr 49: 346352

2. Agerholm- Larsen L, Raben A, Haulrik N, Hansen AS, Manders M and Astray A, 2000. Effect of 8 weeks intake of probiotic milk products on risk factors for cardiovascular diseases. Eur J Clin Nutr 54: 288-297.

3. AOAC, 2005. Official methods of Analysis of the Association of Official Analytical Chemists. Vol 11, AOAC Arlington, VA.

4. Anderson JW and Gilliand SE, 1999. Effect of fermented milk (yoghurt) containing Lactobaccilus acidophilus L.I on serum cholesterol in hypercholesteromic humans. J Am Coll Nut 18: 43-50.

5. Ataie- Jafari A, Larijani B, Majid HA and Tahbaz F, 2009 Cholesterol-lowering effect of probiotic yoghurt in comparison with ordinary yoghurt in mildly to moderately hypercholesterolemic subjects. Ann Nutr Metab54: 2227.

6. Belewu MA and Abodunrin OA, 2005. Preparation of kunnu from unexpected rich food sources, tigernut (Cyperus esculentus). Pake .J.Nutr, 7: 109-111

7. Dhawale S and LaMaster A, 2003. Microbiology Laboratory Manual. The McGraw Hill Companies Incorporation, USA

8. Farinde EO, Obatulu VA, Fasoyiro SB, Adeniran AH and Agboola ER, 2008.Use of alternative raw materials for yoghurt production Afri.J. of Biotechn.79(18): 3339 3324

9. Flyod $\mathrm{M}$ and Brandon DL, 1995. Nutritional and Health Benefits of soy protein. J.Agric. Food Chem. 499(3): 1069-1086.

10. Imele $\mathrm{H}$ and Atemnkeng A, 2001. Preliminary Study of the Utilisation of Coconut in Yoghurt Production. J. Food.

Technol. 6: 121-125.

11. Iwe MO, 2002. Use of natural flaourants to improve soy acceptability. Nigerian food Journal .11: 16-24.

12. Lestiyani AD, Suseno TI and Srianta I, 2014. Characteristics of Soy CornYogurt. J Food Nutr Disor 3:2 http://dx.doi.org/10.4172/2324-9323.1000134

13. Lourens-Hattingh A and Viljoen BC, 2001. Yoghurt as probiotic carrier food (a review). Int Dairy J 11:1-17. http://dx.doi.org/10.1016/S0958-6946 (01)00036

14. Makanjuola OM, 2012. Production and Quality Evaluation of Soy-Corn yoghurt. Advance Journal of Food Science and Technology 4: 130-134.

15. Moore B, 2004. Yoghurt. The Australian Oxford Dictionary. $2^{\text {nd }}$ Ed., Oxford University Press, London.

16. Osho SM, 1991. Soybean as food in Nigeria. Training Manual. IITA. 11-20.

17. .Popoola TOS, Kolapo AI and Afolabi OR. 2007. Biochemical deterioration of soybean daddawa(A condiment). J. Food Agric. Environ. 5(1): 67-70.

18. Rigdal EN, 2000. Treatment of recurrent vulvo vaginal candiadiasis. Am. Family Physician 61: 11

19. Salje KO, Baishie ME and Mokher EI, 2006 Microbiological Studies on Raw milk and yoghurt in Elibeda City. Available from; $w w w$. Devilfinder.com

20. Supavititpatana P, Wirjantoro TI, Koon A and Raviyan P, 2007. Addition of gelation to Corn-milk yoghurt. Food Chem: 211-216.

21. Supavititpatana P, Wirnjantoro TI and Raviyan P, 2010 Characteristics and shelf life of Corn milk yoghurt. CMUJ. Nut Sci 9: 133-150.

22. Tamime AY and Robinson KK, 1989. Yoghurt, Science and Technology (Reprint. First Ed. Pergamon Press, New York). 